
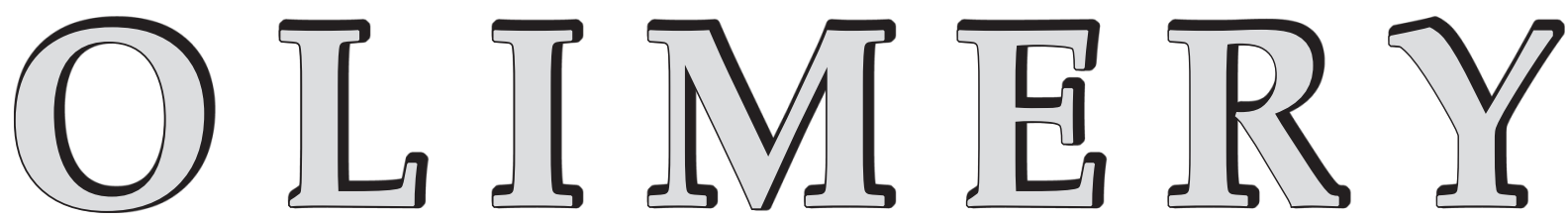

CZASOPISMO POŚWIĘCONE CHEMII, TECHNOLOGII i PRZETWÓRSTWU POLIMERÓW

\title{
Polymers in medicine - direction of development
}

\author{
Andrzej Dworak ${ }^{1)}$, $)$, Alicja Utrata-Wesołek ${ }^{1)}$, Łukasz Otulakowski ${ }^{1)}$, Maciej Kasprów ${ }^{11}$, \\ Barbara Trzebicka ${ }^{1)}$
}

DOI: dx.doi.org/10.14314/polimery.2019.10.1

\begin{abstract}
The paper constitutes a brief and subjective review of polymeric materials in the contemporary health service. The range of applications of polymeric materials is discussed, special attention being paid to such materials for the development of carriers of pharmaceutically active species, stents and vascular prostheses, amongst them to the application of "smart" materials for these purposes, layers and scaffolds for the growth of organs and tissues, antifouling layers. The authors try to turn the attention of the reader to the research and intellectual efforts necessary for the development of polymeric materials for the medicine, and conclude about the growing importance of such studies.
\end{abstract}

Keywords: polymeric materials in medicine, "intelligent" materials, drug carriers, vascular stents and prostheses, orthopedic implants, tissue culture substrates, antifouling layers.

\section{Polimery w medycynie - kierunki rozwoju}

Streszczenie: Artykuł stanowi skrótowy, subiektywny przegląd materiałów polimerowych wykorzystywanych we współczesnej ochronie zdrowia. W pracy skupiono się na zastosowaniach materiałów polimerowych do konstrukcji nośników leków, stentów i protez naczyń, w tym także na użyciu polimerowych materiałów „inteligentnych”, implantów ortopedycznych oraz podłoży i rusztowań do hodowli komórek lub tkanek, a także warstw zapobiegających porastaniu wszczepionych konstruktów. Autorzy zwracają uwagę na znaczny wysiłek badawczy i intelektualny, niezbędny w procesie opracowania materiałów polimerowych dla medycyny, i na stale rosnące znaczenie takich badań.

Słowa kluczowe: materiały polimerowe w medycynie, materiały „inteligentne”, nośniki leków, stenty i protezy naczyniowe, implanty ortopedyczne, podłoża do hodowli tkanek, warstwy przeciwporostowe.

The contemporary economy produces a considerable amount of polymers and materials based upon them. It is estimated that more than ca. 300 million tons of polymer materials are manufactured yearly. The majority of these materials is used in the "gross tonnage" branches

\footnotetext{
1) Centre of Polymer and Carbon Materials (CMPW), Polish Academy of Sciences (PAN), Marii Skłodowskiej-Curie 34, 41-819 Zabrze, Poland.

*) Author for correspondence;

e-mail: adworak@cmpw-pan.edu.pl
}

of industry: packaging, household appliances, textiles, automobile, and building construction. It is difficult to estimate the scale of production destined for biomedical application. The mass production value is misleading. It is known that the price of the same materials, based upon very similar polymers, may vary significantly depending upon imposed conditions and envisaged applications.

It may be estimated that the current value of polymers manufactured for biomedical applications exceeds 10 billion dollars yearly. This annual value is expected to grow 
rapidly, by at least $8 \%$, which is faster than the global growth of manufactured polymer products.

Materials that use synthetic or natural polymers have many advantages, permitting their use in biomedicine.

Many polymer-based materials are biocompatible or can be made biocompatible with appropriate manufacturing and processing. The polymer materials are easy to keep clean, as they frequently are able to withstand the conditions of different sterilization processes. Many of these materials are stable, which makes their long-term use in contact with the living body feasible. Some materials undergo different degradation processes in contact with the biologically active medium, and the degradation products are frequently well tolerated by the living body.

The easy modification of many polymers and the materials obtained from them is equally important. This modification facilitates necessary biological functions (e.g., carriers of pharmaceutically active species, diagnotics, and theranostics). Sometimes rather complex shape, necessary for certain applications, may be impressed easily.

These factors show that the polymer materials are an inherent component of modern medicine.

\section{POLYMERS FOR MANUFACTURING MEDICAL DEVICES AND MATERIALS}

The polymer materials used for manufacturing medical devices have been the subject of numerous reviews [1-3]. These reviews emphasise the importance of polymer materials for health service.

This paper describes the variety of polymers and the devices composed of them. It is necessary to limit this discussion to problems originating from the research praxis of the authors and cooperating groups.

\section{Polymeric carriers of therapeutics: conjugates, nanoparticles, polymeric gels, and hydrogels}

Numerous requirements imposed upon healing products make the choice of proper formulation of medicine a constant challenge for pharmacists. Many contemporary medicines are active as healing agents only in a relative narrow range of concentrations. If this range is exceeded, the species may become toxic and cause undesired side effects. Conversely, if the concentration falls below a certain value, the product's healing action will be reduced significantly.

The polymers are applied to secure the transportation of the drug, to protect the healing species from the destructive action of the body fluids, and to achieve the proper action of the therapeutics, diagnostics, or contrasting species. The polymeric carriers are schematically presented in Fig. 1.

In many cases is requested that the therapeutics is (mostly covalent) attached to the polymer chain. The phar-

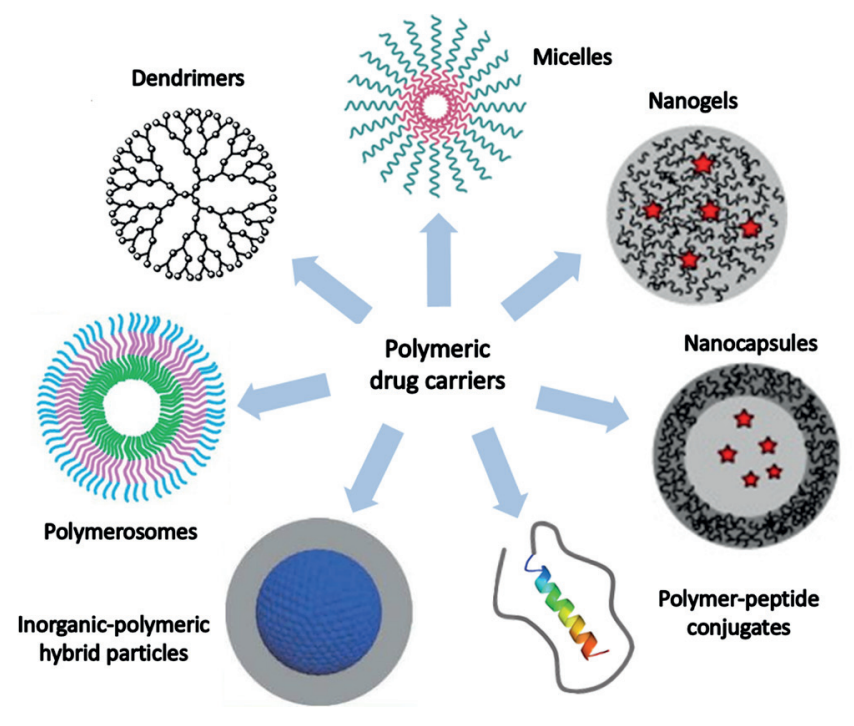

Fig. 1. Types of polymeric carriers

maceutics or the diagnostic element connected to the chain forms the conjugate. Such a connection ensures the safe transportation of the pharmaceutics and their controlled release, even if the conjugate itself is not biologically active $[4,5]$.

Particles where the active species are encapsulated are more complex. The carrier has to protect the active species during transportation and secure its (controlled) release. It may be equipped with elements permitting the detection of the desired place (tropic elements).

The size of the particles is an important problem in designing the polymeric carriers. This parameter determines whether the carriers enter the cell (endocytosis); it is also important for determining the possibility of renal secretion from the body.

Frequently applied and extensively researched are micellar systems, which encapsulate the (mostly hydrophobic) pharmaceutics inside of a polymer micelle, and are formed via the self-organization of amphiphilic polymer chains [6-9]. The polymeric micelle has to meet many requirements concerning its interactions with the organs and the proper mechanism for releasing pharmaceutics. Also, it should have proper shelf-life.

Polymeric structures resembling micelle, which are often used as drug carriers, are polymeric stars, or molecules with macromolecular arms covalently linked with a central unit - the core. Their carrier functions were widely described [10-13].

Amphiphilic polymers may also aggregate to vesicular structures called polymerosomes that are intensively studied as carriers. A hydrophilic drug is placed in an internal water bubble surrounded by a polymeric bilayer. The carrier structure resembles liposomes, vesicular aggregates of lipids used in practice for carriers of doxorubicin (i.e., drugs under trade names Doxil and Caelyx [14]). Detailed information about polymerosomes as carriers, the polymers used for their formation, and the entrapped payload are easily available $[9,15,16]$. 
Presently, increasing efforts are spent on the formation of the carrier via the properly controlled self-organization of biocompatible thermoresponsiveness polymers. Such methods, using the thermoresponsivity of a polymer to form the particles of desired size, have been described inter alia for the formation of the carriers of doxorubicin, therapeutic peptides, and other species [17-19].

To prolong the circulation time of carriers in the blood stream and to improve their biocompatibility, PEGylation is frequently applied [20-21]. This process consists of covering the surface of particles by a layer of poly(ethylene oxide) of rather low molar mass.

The aim of the research on nanoparticles is to synthesize theranostics, which are carriers of pharmaceutically active species fulfilling the functions of diagnostics and therapy simultaneously [22-24]. This research however, did not reach the scale of manufacturing commercially available medicines.

In the field of tissue engineering and regenerative medicine, in situ forming hydrogels (so-called injectable gels) have gained significant interest. They can be used as delivery systems of therapeutic substances (drugs, cells, genes, growth factors, proteins, etc.) $[25,26]$. The precursors of in situ forming hydrogels undergo spontaneous gelation. The obtained material is soft and flexible, which minimizes the mechanical irritation of the surrounding tissue. Therapeutic substances are mixed with the injected material prior to application. Injectable gels are an excellent base for localized drug delivery, for example, in the treatment of cancer, gene therapy, or chemoimmunotherapy $[27,28]$.

In situ hydrogels can be prepared by chemical or physical crosslinking of polymers [25, 29,30]. Chemical crosslinking, leading to the formation of covalent bonds in the hydrogel structure, takes place according to the radical mechanism (e.g., photoinitiated crosslinking), in classical organic reactions (e.g., "click chemistry", Michael addition, Schiff reaction, or formation of disulphide bridges), and during enzymatic reactions. Physically crosslinked hydrogels are generated as a result of changes in environmental conditions (e.g., as a result of hydrophobic or ionic interactions, or formation of stereocomplexes). Compared with chemically crosslinked in situ hydrogels, physically crosslinked hydrogels possess more advantages, including eliminating the need for crosslinking agents and photoinitiated crosslinking, and being a solvent-free procedure with no toxic catalysts or other additives.

Among physically crosslinked in situ hydrogels, the most promising ones are obtained during thermogelation. Thermogels are formed during the physical conversion of sol-gel stimulated by changes in temperature [31-33]. Polymers that undergo thermogelation are based on natural polymers such as chitosan, hyaluronic acid, gelatin, and amylopectin [29, 32], or synthetic ones such as amphiphilic block copolymers of poly(ethylene oxide) (PEG) and poly(propylene oxide) (PPG) [34], PEG-b-polyester copolymers where the polyester can be polylactide (PLA), polyglycolide (PGA), poly(lactide-co-glycolide) (PLGA) or polycaprolactone (PCL) [34-36], polymers based on $N$-isopropylacrylamide (PNIPAM) [37-41], and polymers based on oligo(ethylene glycol) methacrylates [42-50].

\section{Polymeric stents and prostheses of vessels}

The diseases of coronary arteria, which causes narrowing of the vessels delivering the oxygenated blood to the heart muscle, is currently one of the most frequent causes of death in developed countries [51]. Stents and prostheses are frequently used in invasive cardiology. The coronary stents are structural scaffolds, designed primarily to protect the deformations and hyperplasia of the internal membranes of the vesicles [52]. They are manufactured of metal (the standard) or of biocompatible, at best simultaneously biodegradable polymers, which disintegrate after serving their function. Such stents frequently contain medicine preventing restenosis (i.e., repeated clogging of the vessel).

To manufacture polymeric scaffolds in most cases, poly(L-lactide), poly(D-lactide), poly(D,L-lactide), poly(D,L-lactide-co-glycolide), polycaprolacton, or desaminotyrosine polycarbonate (PTD-PC) are applied [53].

Polylactide is a bioresorbable polyester that has been applied frequently in degradable implants, surgical sutures, and scaffolds [54,55]. PLA is frequently applied to manufacture stents for the treatment of the diseases of arteries. It is degradable via the hydrolysis of ester bonds. This process is catalyzed by lactic acid, a degradation product [56]. This is an important design factor that makes the control of the degradation time, through proper design of the polymer structure, possible [57-59].

Polycaprolactone was among the first synthetic polymers obtained by the pioneering group of Carothers in the early thirties [60]. This polymer degrades much slower than PLA (half-time up to 10 years). PCL has better rheological and viscoelastic properties than many comparable aliphatic polyesters. Caprolactone may also be copolymerized with other monomers to modify properties [61].

Easy manufacturing and Federal Drug Administration of the US approval of medical devices made of this material are responsible for its widespread application.

Biodegradable stents were first developed in 1980 by Stack and Clark [62]. Since then, many polymeric stents are commercially available and widely applied. Table 1 contains some examples of commercially available stents applied in the healing praxis.

The use of the so-called shape memory polymers for the above-discussed devices extends the possibilities of application. The shape memory materials return to their initially imprinted shape as the result of an external stimulus, in most cases temperature. Many such materials are based upon copolymers exhibiting microphase separation. The transition temperature may be controlled in 
T a b l e 1. Commercially available polymer stents

\begin{tabular}{|c|c|c|c|c|}
\hline Manufacturer & Stent & Material & Polymer layer & Medicine \\
\hline Abbott & $\begin{array}{l}\text { Absorb } 1.0 \\
\text { Absorb } 1.1\end{array}$ & PLLA & $\begin{array}{l}\text { PDLLA } \\
\text { PDLLA }\end{array}$ & $\begin{array}{l}\text { Everolimus } \\
\text { Everolimus }\end{array}$ \\
\hline Elixir Medical & $\begin{array}{c}\text { Desolve } \\
\text { Desolve100 }\end{array}$ & PLLA & $\begin{array}{c}- \\
\text { PLLA }\end{array}$ & $\begin{array}{l}\text { Miolimus } \\
\text { Novolimus }\end{array}$ \\
\hline Meril Medical & $\begin{array}{c}\text { MeRes } \\
\text { MeRes100 }\end{array}$ & $\begin{array}{c}\text { PLLA } \\
\text { PLLA }(200-220 \mathrm{kDa})\end{array}$ & $\begin{array}{c}\text { Biodegradable polymer } \\
\text { PDLLA }\end{array}$ & $\begin{array}{l}\text { Sirolimus } \\
\text { Sirolimus }\end{array}$ \\
\hline Amaranth & $\begin{array}{l}\text { FORTITUDE } \\
\text { APTITUDE } \\
\text { MAGNITUDE }\end{array}$ & $\begin{array}{l}\text { PLLA (100-120 kDa) } \\
\text { Amorphous PLLA }\end{array}$ & $\begin{array}{l}- \\
- \\
-\end{array}$ & $\begin{array}{l}\text { Sirolimus } \\
\text { Sirolimus } \\
\text { - }\end{array}$ \\
\hline $\begin{array}{l}\text { Huaan Biotechnology } \\
\text { Group }\end{array}$ & XINSORB & PLLA & PDLLA/PLLA & Sirolimus \\
\hline $\begin{array}{l}\text { Bioabsorbable } \\
\text { Therapeutics }\end{array}$ & $\begin{array}{l}\text { IDEAL I } \\
\text { IDEAL II }\end{array}$ & $\begin{array}{l}\text { PLLA/Salicylates } \\
\text { PLLA/Salicylates }\end{array}$ & $\begin{array}{l}\text { SA/AA } \\
\text { SA/AA }\end{array}$ & $\begin{array}{l}\text { Sirolimus } \\
\text { Sirolimus }\end{array}$ \\
\hline Manli Cardiology & Mirage & PLLA & PLA & Sirolimus \\
\hline Kyoto Medical & Igaki-Tamai & PLLA (183 kDa) & - & - \\
\hline Arterius & $\begin{array}{l}\text { ArterioSorb } 120 \\
\text { ArterioSorb } 95\end{array}$ & PLLA & $\begin{array}{l}\text { PDLA } \\
\text { PDLA }\end{array}$ & $\begin{array}{l}\text { Sirolimus } \\
\text { Sirolimus }\end{array}$ \\
\hline $\begin{array}{l}\text { Arterial Remodelling } \\
\text { Technologies }\end{array}$ & ART18Z & PDLLA & - & Sirolimus \\
\hline OrbusNeich & ON-AVS & PLLA/PDLA & - & Sirolimus \& CD34+ \\
\hline Cardionovum & ReNATURAL (P) & PLLA & - & Sirolimus \\
\hline 480 Biomedical & Stanza BRS & PLGA & $\begin{array}{l}\text { Cross-linked polyester/ } \\
\text { polyurethane }\end{array}$ & - \\
\hline Reva Medical & $\begin{array}{c}\text { REVA } \\
\text { ReZolve } \\
\text { ReZolve } 2 \\
\text { Fantom }\end{array}$ & $\begin{array}{l}\text { PTD-PC } \\
\text { PTD-PC } \\
\text { PTD-PC } \\
\text { PTD-PC }\end{array}$ & $\begin{array}{l}- \\
- \\
- \\
-\end{array}$ & $\begin{array}{c}\text { - } \\
\text { Sirolimus } \\
\text { Sirolimus } \\
\text { Sirolimus }\end{array}$ \\
\hline
\end{tabular}

a relatively wide range. Such materials are used a.o. for the manufacturing of surgical staples, shrinking under the influence of body temperature.

An example of the application of shape memory polymers for making stents is a stent made of the poly(lactide-co-glycolide-co-methylene tricarbonate) terpolymers (Fig. 2).

The "cold" shrunken stent may be introduced into the body easily. It expands based on the body temperature. After it has fulfilled its function, it degrades to biocompatible products. The formation of the stent is rather complex, requiring research in addition to that of medical doctors, synthetic polymer chemists, and polymer processing specialists.

\section{Polymeric orthopedic implants}

Since the first bone transplantation in 1668 aimed at repairing the skull of a wounded soldier using the bones of a dog skull [63], many aspects concerning the regeneration of the bone tissue have changed. Presently, the bone tissue may be replaced by metal, ceramics, or polymer-based materials of properties mimicking the replaced tissue [64, 65]. Metals and ceramics have to be removed in the next surgery, if their permanent function is not desired $[65,66]$.

A frequent problem in the application of the implants is the rejection of the implant by the organism. The tissue engineering tries to solve this problem by inserting into the implanted scaffold autogenic cells [67]. 
a)

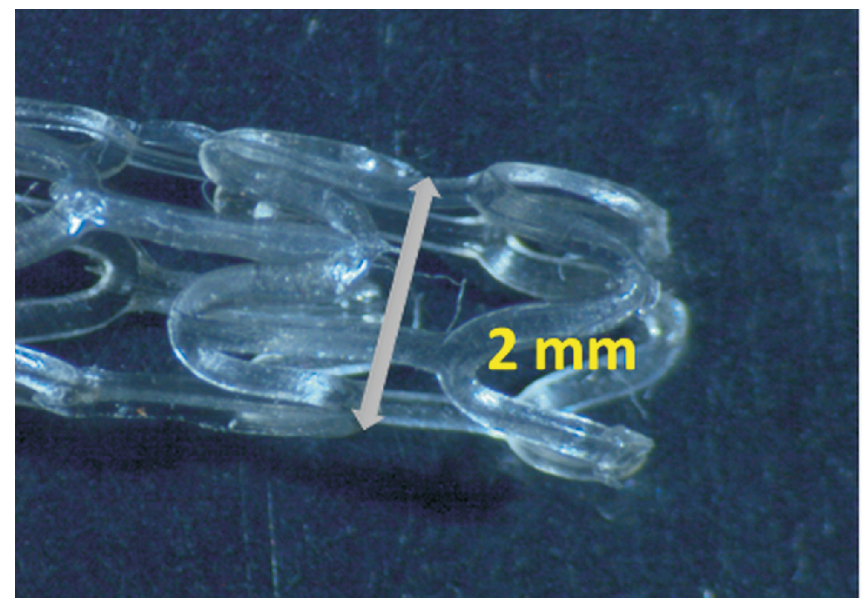

b)

Fig. 2. Stent made of poly(lactide-co-glicolide-co-trimethylene carbonate): a) "shrunken" form, b) stent "expanded" under the influence of body heat (Figures kindly supplied by Prof. P. Dobrzyński, CMPW PAN)

The polymer materials used in the bone prosthetics have to be biocompatible, exhibit proper mechanical parameters, be stable under sterilization conditions, and have a highly developed porous structure enabling the proliferation and growth of cells [64, 68-70]. Many implants contain hydroxyapatite, the inorganic component of the bones that stimulate the osteosynthesis.

The replacement of the joints calls for non-degradable materials of high mechanical strength that are resistant to friction and have a low friction coefficient [71]. Polyethylene of ultra-high molecular weight (UHMWPE) meets these requirements [72]. Although it is resistant to friction, fine powder is formed within the joint after some time, which causes inflammation and can lead to transplant rejection.

It is possible to strengthen the implant. Several materials could be added to the UHMWPE for improving its mechanical properties, among them carbon fibers, forming composites [72].

An alternative for UHMWPE are poly(urethane carbonate)s (PUC) [72-75]. This material is softer than UHMWPE so it better simulates the mechanical and lubrication properties of the joint cartilage. The grinding is at least $20 \%$ lower than that of UHMWPE, and the generated powder is less likely to induce inflammatory conditions.

Silicones are most frequently used as implants for small joints, (e.g., in the hand or foot) [76]. They are very stable and highly biocompatible.

To replace the loss of the bone tissue, 3D scaffolds of proper size and low pore size distribution are used. They support the regeneration of bone tissue and ensure its good mechanical stability [77, 78]. In most cases, constructs made from biodegradable polymers are used, like polylactides, polyglycolides, and their copolymers [65, 79]. Other polymers of potential importance for bone regeneration are polycarbonates [80], polyanhydrides [81], polyphosphazenes [82], and polyfumarates [83].

Frequently are used injectable implants formed after the solidification of injected fluids [69, 76]. The solidifi- cation of the implant results from chemical or physical crosslinking or from the phase transition of polymer in the injected polymeric system under the action of an external stimulus (e.g., light, $\mathrm{pH}$, temperature, or change of solvent). The implants formed in situ make the surgical intervention obsolete, and they fit well to surrounding tissue [69]. KRYPTONITE® is an example of a clinically applied injectable system [69].

Other examples of used polymers are polyurethanes based upon pentaerythritol or PEG/PCL/PEG terpolymer with collagen and hydroxyapatite, solidifying under action of temperature and poly(propylene fumarate), which chemically crosslink in situ [84].

Polymers based upon aliphatic polyesters, specifically PLA and PLGA, are also applied as bonding materials (e.g., screws, pins, and clamps), replacing Ti-alloys [76].

\section{Polymer-peptide substrates - "lab on a chip"}

Present diagnostics call for simple and possibly universal instruments that would accelerate the analytical process.

Peptides or proteins placed in a regular, orderly manner on a carrier form the so-called matrix. Such matrices are used in biochemical analytics, in clinical diagnostics, and in pharmacy.

The ordering of the matrix into microspots allows for several hundred analyses to occur simultaneously, while a minimal amount of the valuable biological material is used.

The application of a polymeric substrate changes the surface properties of the matrix, for example by reducing the undesired absorption of bioparticles, increases the density of the functional groups, or improves the bioaccessibility of biomolecules. As substrate for the formation of matrices polymers like poly(methyl methacrylate), polycarbonates, poly(ethylene oxide), or poly(diethyl siloxanes) are applied [85, 86].

Polymers are also used as intermediate layers, hydrogels, or films placed between the matrix and the peptides 
or protein. The hydrogel layer is formed by polyacrylamide $[87,88]$ or agarose [89], the polymeric films by polylysine [90] or poly(ethylene imine) [91]. Recent research has shown that the introduction of a polymeric linker between the peptide or protein and the substrate may improve the quality of the analyses [92, 93]. Poly(ethylene oxide) [92, 94-96], polymethacrylates [97-99], and different dendritic polymers may be used as linkers [97, 100, 101]. The linker improves the accessibility of the biomolecules, resulting in a faster and more efficient reaction of the biomolecule for analysis [102].

\section{Substrates and scaffolds for cell and tissue culture}

The culture of cells, tissues, and organs is an important task of modern regenerative medicine. A long-term goal is to obtain biocompatible and non-immunogenic organs.

Currently, in medical practice, the most commonly used substrate for cell culture is modified polystyrene (tissue culture polystyrene or TCPS). In order to separate the proliferated cells, the enzymatic methods are used, which unfortunately destroy a certain number of cells and disturb their integrity.

The application in culture of cells substrates made of thermoresponsive polymers created new possibilities (Fig. 3). The use of these substrates and application of appropriate procedures allow for obtaining an integral cell sheet. The reversible affinity to water of these substrates to the surrounding liquid, in response to relatively small changes of temperature, leads to spontaneous detachment of the cells from the thermoresponsive support, which becomes hydrophilic below the transition temperature.

The first works of the T. Okano group on the use of thermoresponsive poly(N-isopropylacrylamide) (PNIPAM) sub-

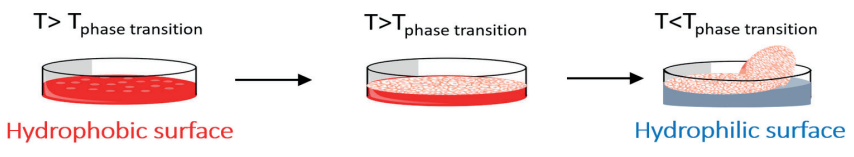

Fig. 3. Concept of cell sheet culture and harvesting with the use of "intelligent" surfaces

strates were published in the 1990s [103, 104]. PNIPAM and its copolymers are currently the most widely studied group of polymers used in cell engineering [105-107]. PNIPAM surfaces were used to prepare sheets from various cell types, such as, bovine aortic endothelial cells, fibroblasts, muscle cells, kidney cells, cardiac myocytes, cells, epithelial cells, hepatocytes, and chondrocytes [108-110].

In cell engineering, thermoresponsive polymers based on oligo(ethylene glycol) methacrylates [111-116], oxazolines [117-120], and ethers [121, 122] were also applied.

Another group in cell and tissue cultures are three-dimensional structures with a developed structure. Obtaining three-dimensional structures with pores of defined dimensions is possible by various methods, including 3D printing, laser perforation, or electrospinning. Various polymers and copolymers are used to make such a scaffold, including alginates, PLGA-based copolymer, polycaprolactone, poly(propylene fumarate), and others (Table 2) [123-129]. Such scaffolds allow the growth of various types of cells both on the surface and inside the porous structure and, therefore, the regeneration of the damaged tissue.

\section{Antifouling surfaces}

Most materials, after a few seconds of contact with physiological fluids and tissues, become covered with

T a b l e 2. 3D scaffolds for cell culture

\begin{tabular}{|c|c|c|c|c|}
\hline Material & $\begin{array}{l}\text { Manufacturing } \\
\text { method }\end{array}$ & Encapsulated cells & Remarks & Ref. \\
\hline $\begin{array}{l}\text { Alginate } \\
\text { hydrogel }\end{array}$ & $\begin{array}{l}\text { Sedimentation of } \\
\text { 3D fibres }\end{array}$ & $\begin{array}{l}\text { Human chondrocytes and } \\
\text { osteogenic precursors }\end{array}$ & $\begin{array}{l}\text { Possible repair of osteal and } \\
\text { cartillageous defects }\end{array}$ & [123] \\
\hline $\begin{array}{l}\text { Gelatine } \\
\text { methacrylate }\end{array}$ & $\begin{array}{l}\text { Projection } \\
\text { stereolithography }\end{array}$ & $\begin{array}{l}\text { Human cells from the endothelia of } \\
\text { the umbilical vein }\end{array}$ & Biological functionality of scaffolds & [124] \\
\hline PCL & Molten material & $\begin{array}{l}\text { Human fibroblasts and periosteum } \\
\text { cells }\end{array}$ & $\begin{array}{l}\text { Possible use in tissue engineering of } \\
\text { osteoal and cartillageous tissue }\end{array}$ & [125] \\
\hline PCL & $\begin{array}{l}\text { Selective laser } \\
\text { sintering }\end{array}$ & Fibroblasts & Accelerated growth of tissue & [126] \\
\hline PCL & $3 \mathrm{D}$ printing & $\begin{array}{l}\text { Fat tissue, cartilage tissue, heart } \\
\text { muscle tissue }\end{array}$ & $\begin{array}{l}\text { High viability and functionality } \\
\text { of cells, accelerated growth of } \\
\text { myoblasts }\end{array}$ & [127] \\
\hline PLGA & 3D printing & $\begin{array}{c}\text { Hepatocytes } \\
\text { Lewis rats liver non-parenchymal } \\
\text { cells }\end{array}$ & $\begin{array}{c}\text { Good adhesion and improved } \\
\text { viability of cells in static and flow } \\
\text { conditions }\end{array}$ & [128] \\
\hline PLGA & $\begin{array}{l}\text { Evaporation of } \\
\text { solvent - salt } \\
\text { washing }\end{array}$ & Mezenchymal stem cells & $\begin{array}{l}\text { Chondriditic activity of cells } \\
\text { cultured on PLGA substrate }\end{array}$ & [129] \\
\hline $\begin{array}{l}\text { Hydroxyapatite/ } \\
\text { PLGA }\end{array}$ & $\begin{array}{l}\text { Low temperature } \\
\text { sedimentation }\end{array}$ & Chondrocytes from rabbit fetus & $\begin{array}{l}\text { Good biocompatibility, proper pore } \\
\text { size and pore distribution }\end{array}$ & [106] \\
\hline
\end{tabular}


a layer of proteins. This phenomenon is known as biofouling [130]. In many cases, biofouling is harmful and contributes to the deterioration of the functions of medical devices, including stents and vessel prostheses, and leads to inflammation. Covering the material from which the prosthesis is made with a polymer layer with special properties may present a solution. For this purpose, materials based on zwitterionic polymers, hydrophilic, or superhydrophobic polymers are usually used. The most frequently studied polymers containing zwitterions are poly(sulfobetaine), poly(carboxybetaine), and poly(phosphorylcholine) [131, 132]. Hydrophilic materials that prevent surface biofouling include PEG, oligo(ethylene glycol)s, poly(methacrylates of ethylene glycol), polyacrylamides, polysaccharides, and polyglycidol [132-137]. The antifouling properties of hydrophilic and zwitterionic materials are related to the formation of a hydration layer on the surface of the material [138, 139]. In the case of hydrophilic coatings, the hydration layer arises as a result of hydrogen bonding between the polymer functional groups on the surface of the material and water molecules. Materials containing zwitterions prevent non-specific adhesion of biological agents by keeping the inert surface on the material and creating a hydration layer closely bound by electrostatic interactions. The interaction of these coatings with the biological environment is complex and depends on many physicochemical parameters of the polymer and its packing on the surface.

The antifouling properties of superhydrophobic coatings result from the presence in their structure of special functional groups [such as fluorinated (meth)acrylates] that do not form hydrogen bonds on the surface of the material. As a result, such coatings prevent the formation of the hydration layer and cause repulsion of the biologically active substance [140].

\section{SUMMARY}

This review, necessarily very short and limited by the research interest of the authors, proves the widespread application of polymers in medicine, first of all of synthetic polymers. It is the opinion of the authors that the volume or price indices, noting the biomedical applications of polymers, are only of limited importance because of the specific character of such materials that strongly influences their price. The significant amount of research necessary to develop and translate such materials must be stressed. The authors are convinced that such knowledge-based materials will decide the progress of health service in coming years.

\section{REFERENCES}

[1] Sobczak M., Olędzka E., Kołodziejski W.L., Kuźmicz R.: Polimery 2007, 52, 411.

[2] Olędzka E., Sobczak M., Kołodziejski W.L.: Polimery 2007, 52, 793.
[3] Puoci F.: "Advanced Polymers in Medicine”, Springer, Cham 2015.

http://dx.doi.org/10.1007/978-3-319-12478-0

[4] Tsuchikama K., An Z.: Protein \& Cell 2018, 9, 33.

http://dx.doi.org/10.1007/s13238-016-0323-0

[5] Trzebicka B., Szweda R., Kosowski D. et al.: Progress in Polymer Science 2016, 68, 35.

https://doi.org/10.1016/j.progpolymsci.2016.12.004

[6] Kataoka K., Harada A., Nagasaki Y.: Advanced Drug Delivery Reviews 2012, 64, 37.

https://doi.org/10.1016/j.addr.2012.09.013

[7] Kowalczuk A., Trzcinska R., Trzebicka B. et al.: Progress in Polymer Science 2014, 39, 43.

https://doi.org/10.1016/j.progpolymsci.2013.10.004

[8] Petrov P.D., Yoncheva K., Gancheva V. et al.: European Polymer Journal 2016, 81, 24.

https://doi.org/10.1016/j.eurpolymj.2016.05.010

[9] Letchford K., Burt H.: European Journal of Pharmaceutics and Biopharmaceutics 2007, 65, 259.

https://doi.org/10.1016/j.ejpb.2006.11.009

[10] Ren J.M., McKenzie T.G., Fu Q. et al.: Chemical Review 2016, 116, 6743.

http://dx.doi.org/10.1021/acs.chemrev.6b00008

[11] Wu W., Wang W., Li J.: Progress in Polymer Science 2015, 46, 55 .

https://doi.org/10.1016/j.progpolymsci.2015.02.002

[12] Mendrek B., Sieroń Ł., Libera M. et al.: Polymer (Guildf) 2014, 55, 4551.

https://doi.org/10.1016/j.polymer.2014.07.013

[13] Mendrek B., Sieroń Ł., Żymełka-Miara I. et al.: Biomacromolecules 2015, 16, 3275.

http://dx.doi.org/10.1021/acs.biomac.5b00948

[14] Barenholz Y.: Journal of Controlled Release 2012, 160, 117.

https://doi.org/10.1016/j.jconrel.2012.03.020

[15] Discher B.M., Won Y.Y., Ege D.S. et al.: Science 1999, 284, 1143 .

http://dx.doi.org/10.1126/science.284.5417.1143

[16] Lee J.S., Feijen J.: Journal of Controlled Release 2012, $161,473$.

https://doi.org/10.1016/j.jconrel.2011.10.005

[17] Szweda R., Trzebicka B., Dworak A. et al.: Biomacromolecules 2016, 17, 8 .

http://dx.doi.org/10.1021/acs.biomac.6b00725

[18] Lipowska-Kur D., Szweda R., Trzebicka B., Dworak A.: European Polymer Journal 2018, 109, 391. https://doi.org/10.1016/j.eurpolymj.2018.10.008

[19] Haladjova E., Toncheva-Moncheva N., Apostolova M.D. et al.: Biomacromolecules 2014, 15, 4377. http://dx.doi.org/10.1021/bm501194g

[20] Veronese F.M.: Biomaterials 2001, 22, 405. https://doi.org/10.1016/S0142-9612(00)00193-9

[21] Riaz K.M., Riaz A.M., Zhang X. et al.: International Journal of Molecular Sciences 2018, 19, 195. http://dx.doi.org/10.3390/ijms19010195

[22] Cole A.J., Yang V.C., David A.E.: Trends in Biotechnology 2011, 29, 323. 
https://doi.org/10.1016/j.tibtech.2011.03.001

[23] Lim E.K., Kim T., Paik S. et al.: Chemical Review 2015 , 115, 327.

http://dx.doi.org/10.1021/cr300213b

[24] Lammers T., Aime S., Hennink W.E. et al.: Accounts of Chemical Research 2011, 44, 1029. http://dx.doi.org/10.1021/ar200019c

[25] Sivashanmugam A., Arun Kumar R., Vishnu Priya M. et al.: European Polymer Journal 2015, 72, 543. https://doi.org/10.1016/j.eurpolymj.2015.05.014

[26] Mathew A.P., Uthaman S., Cho K.H. et al.: International Journal of Biological Macromolecules 2018, 110, 17. https://doi.org/10.1016/j.ijbiomac.2017.11.113

[27] Dimatteo R., Darling N.J., Segura T.: Advanced Drug Delivery Reviews 2018, 127, 167. https://doi.org/10.1016/j.addr.2018.03.007

[28] Agarwal P., Rupenthal I.D.: Drug Discovery Today 2013, 18, 337. https://doi.org/10.1016/j.drudis.2013.01.013

[29] Vermonden T., Censi R., Hennink W.E.: Chemical Reviews 2012, 112, 2853. http://dx.doi.org/10.1021/cr200157d

[30] Nguyen Q.V., Huynh D.P., Park J.H., Lee D.S.: European Polymer Journal 2015, 72, 602. https://doi.org/10.1016/j.eurpolymj.2015.03.016

[31] Liow S.S., Dou Q., Kai D. et al.: ACS Biomaterials Science and Engineering 2016, 2, 295. http://dx.doi.org/10.1021/acsbiomaterials.5b00515

[32] Li Z., Guan J.: Expert Opinion on Drug Delivery 2011, 8, 991. http://dx.doi.org/10.1517/17425247.2011.581656

[33] Ko D.Y., Shinde U.P., Yeon B., Jeong B.: Progress in Polymer Science 2013, 38, 672. https://doi.org/10.1016/j.progpolymsci.2012.08.002

[34] Jeong B., Kim S.W., Bae Y.H.: Advanced Drug Delivery Reviews 2012, 64, 154.

https://doi.org/10.1016/j.addr.2012.09.012

[35] Alexander A., Ajazuddin Khan J., Saraf S., Saraf S.: Journal of Controlled Release 2013, 172, 715. https://doi.org/10.1016/j.jconrel.2013.10.006

[36] Loh X.J., Young D.J.: „The Royal Society of Chemistry", 2019, p. 186.

http://dx.doi.org/10.1039/9781788012676

[37] Alexander A., Ajazuddin Khan J., Saraf S., Saraf S.: European Journal of Pharmaceutics and Biopharmaceutics 2014, 88, 575. https://doi.org/10.1016/j.ejpb.2014.07.005

[38] Park K.H., Na K.: Journal of Bioscience and Bioengineering 2008, 106, 74.

https://doi.org/10.1263/jbb.106.74

[39] Nam I., Bae J.W., Jee K.S. et al.: Macromolecular Research 2002, 10, 115.

http://dx.doi.org/10.1007/BF03218300

[40] Pollock J.F., Healy K.E.: Acta Biomaterialia 2010, 6, 1307. https://doi.org/10.1016/j.actbio.2009.11.027

[41] Chen J.P., Cheng T.H.: Polymer 2009, 50, 107. https://doi.org/10.1016/j.polymer.2008.10.045
[42] Lei J., Mayer C., Freger V., Ulbricht M.: Macromolecular Materials and Engineering 2013, 298, 967. http://dx.doi.org/10.1002/mame.201200297

[43] Yoon J.A., Kowalewski T., Matyjaszewski K.: Macromolecules 2011, 44, 2261. http://dx.doi.org/10.1021/ma1029696

[44] Yoon J.A., Gayathri C., Gil R.R. et al.: Macromolecules 2010, 43, 4791. http://dx.doi.org/10.1021/ma1004953

[45] Fechler N., Badi N., Schade K. et al.: Macromolecules 2009, 42, 33.

http://dx.doi.org/10.1021/ma8025173

[46] Badi N., Lutz J.F.: Journal of Controlled Release 2009, 140, 224. https://doi.org/10.1016/j.jconrel.2009.04.012

[47] Bakaic E., Smeets N.M.B., Badv M. et al.: ACS Biomaterials Science \& Engineering 2018, 4, 3713. http://dx.doi.org/10.1021/acsbiomaterials.7b00397

[48] Bakaic E., Smeets N.M.B., Dorrington H., Hoare T.: RSC Advances 2015, 5, 33364. http://dx.doi.org/10.1039/C5RA00920K

[49] Smeets N.M.B., Bakaic E., Patenaude M., Hoare T.: Chemical Communications 2014, 50, 3306. http://dx.doi.org/10.1039/C3CC48514E

[50] Urosev I., Bakaic E., Alsop R.J. et al.: Journal of Materials Chemistry B 2016, 4, 6541. http://dx.doi.org/10.1039/C6TB02197B

[51] Cassar A., Holmes D.R., Rihal C.S., Gersh B.J.: Mayo Clinic Proceedings 2009, 84, 1130. https://doi.org/10.4065/mcp.2009.0391

[52] Iqbal J., Gunn J., Serruys P.W.: British Medical Bulletin 2013, 106, 193. http://dx.doi.org/10.1093/bmb/ldt009

[53] McMahon S., Bertollo N., Cearbhaill E.D.O. et al.: Progress in Polymer Science 2018, 83, 79.

https://doi.org/10.1016/j.progpolymsci.2018.05.002

[54] Bergström J.S., Hayman D.: Annals of Biomedical Engineering 2016, 44, 330.

http://dx.doi.org/10.1007/s10439-015-1455-8

[55] Bouapao L., Tsuji H., Tashiro K. et al.: Polymer 2009, 50, 4007. https://doi.org/10.1016/j.polymer.2009.06.040

[56] Lu L., Peter S.J., Lyman M.D. et al.: Biomaterials 2000, 21, 1595. https://doi.org/10.1016/S0142-9612(00)00048-X

[57] Dobrzynski P., Kasperczyk J., Janeczek H., Bero M.: Polymer 2002, 43, 2595.

https://doi.org/10.1016/S0032-3861(02)00079-4

[58] Dobrzynski P., Kasperczyk J., Janeczek H., Bero M.: Macromolecules 2001, 34, 5090. http://dx.doi.org/10.1021/ma0018143

[59] Dobrzyński P., Kasperczyk J., Bero M.: Macromolecules 1999, 32, 4735. http://dx.doi.org/10.1021/ma981969z

[60] Van Natta F.J., Hill J.W., Carothers W.H.: Journal of the American Chemical Society 1934, 56, 455. http://dx.doi.org/10.1021/ja01317a053 
[61] Ali S.A.M., Zhong S.P., Doherty P.J., Williams D.F.: Biomaterials 1993, 14, 648. https://doi.org/10.1016/0142-9612(93)90063-8

[62] Stack R., Califf R., Philips H. et al.: American Journal of Cardiology 1988, 62, F3-4. http://dx.doi.org/10.1016/0002-9149(88)91529-9

[63] De Boer H.: Clinical Orthopaedics and Related Research 1988, NA, 292. http://dx.doi.org/10.1097/00003086-198801000-00037

[64] Kroeze R.J., Helder M.N., Govaert L.E., Smit T.H.: Materials 2009, 2, 833. http://dx.doi.org/10.3390/ma2030833

[65] Liu X., Ma P.X.: Annals of Biomedical Engineering 2004, $32,477$.

ht t p://dx.doi.org / 10.1023 / B : A B M E $.0000017544 .36001 .8 \mathrm{e}$

[66] Maquet V., Jerome R.: Materials Science Forum 1997, 250, 15.

http://dx.doi.org/10.4028/www.scientific.net/ MSF.250.15

[67] Chapekar M.S.: Journal of Biomedical Materials Research 2000, 53, 617.

h t t p : / / d x.doi .org / $10.1002 / 1097$ 4636(2000)53:6<617::AID-JBM1>3.0.CO,2-C

[68] Ma P.X.: Materials Today 2004, 7, 30. https://doi.org/10.1016/S1369-7021(04)00233-0

[69] Śmiga-Matuszowicz M., Korytkowska-Wałach A., Łukaszczyk J.: Polimery 2015, 3, 149.

http://dx.doi.org/10.14314/polimery.2015.149

[70] Ikada Y., Tsuji H.: Macromolecular Rapid Communications 2000, 21, 117.

ht t p://dx.doi.org/10.1002/(SIC I)15213927(20000201)21:3<117::AID-MARC117>3.0.CO,2-X

[71] Affatato S., Jaber S.A., Taddei P.: "Biomaterials in Clinical Practice: Advances in Clinical Research and Medical Devices" (Eds. Zivic F., Affatato S., Trajanovic M., Schnabelrauch M., Grujovic N., Choy K.L.), Cham: Springer International Publishing, 2018, pp. 149-165.

http://dx.doi.org/10.1007/978-3-319-68025-5_6

[72] Spiegelberg S.: “The UHMWPE Handbook”, Chapter 12 (Ed. Kurtz S.M.B.T.-T.U.H.), San Diego: Academic Press, 2004, pp. 263-285.

https://doi.org/10.1016/B978-012429851-4/50013-9

[73] Carbone A., Howie D.W., McGee M. et al.: Journal of Arthroplasty 2006, 21, 899.

https://doi.org/10.1016/j.arth.2005.07.023

[74] Khan I., Smith N., Jones E. et al.: Biomaterials 2005, 26, 621. https://doi.org/10.1016/j.biomaterials.2004.02.065

[75] Scholes S.C., Unsworth A., Jones E.: Physics in Medicine \& Biology 2006, 52, 197. http://dx.doi.org/10.1088/0031-9155/52/1/013

[76] Swanson A.B.: Surgical Clinics of North America 1968, $48,1113$.

https://doi.org/10.1016/S0039-6109(16)38639-X

[77] Budnicka M., Gadomska-Gajadhur A., Ruśkowski P.: Wyroby Medyczne 2017, 4, 147.
[78] Murphy C.M., Haugh M.G., O’Brien F.J.: Biomaterials 2010, 31, 461.

https://doi.org/10.1016/j.biomaterials.2009.09.063

[79] Bose S., Roy M., Bandyopadhyay A.: Trends Biotechnology 2012, 30, 546.

https://doi.org/10.1016/j.tibtech.2012.07.005

[80] Choueka J., Charvet J.L., Koval K.J. et al.: Journal of Biomedical Materials Research 1996, 31, 35.

h t t p ://dx.doi.org/10.1002/(SICI)10974636(199605)31:1<35::AID-JBM5>3.0.CO,2-R

[81] Ibim S.M., Uhrich K.E., Bronson R. et al.: Biomaterials 1998, 19, 941.

https://doi.org/10.1016/S0142-9612(98)00019-2

[82] Laurencin C.T., El-Amin S.F., Ibim S.E. et al.: Journal of Biomedical Materials Research 1996, 30, 133.

h t t p://dx.doi .org/10.1002/(S ICI)10974636(199602)30:2<133::AID-JBM1>3.0.CO,2-S

[83] Peter S.J., Yaszemski M.J.: Journal of Biomaterials Science Polymer Edition 1997, 8, 893.

http://dx.doi.org/10.1163/156856297X00074

[84] Shi C., Yuan Z., Han F. et al.: Ann Joint, November 2016.

[85] Zhu H., Klemic J.F., Chang S. et al.: Nature Genetics 2000, 26, 283. http://dx.doi.org/10.1038/81576

[86] Delamarche E., Bernard A., Schmid H. et al.: Science 1997, 276, 779.

http://dx.doi.org/10.1126/science.276.5313.779

[87] Arenkov P., Kukhtin A., Gemmell A. et al.: Analytical Biochemistry 2000, 278, 123. https://doi.org/10.1006/abio.1999.4363

[88] Afanassiev V., Hanemann V., Wölfl S.: Nucleic Acids Research 2000, 28, e66.

http://dx.doi.org/10.1093/nar/28.12.e66

[89] Sawasaki T., Endo Y.: "Methods in Molecular Biology" (Eds. Endo Y., Takai K., Ueda T.), Totowa, NJ: Humana Press, 2010, pp. 63-72. http://dx.doi.org/10.1007/978-1-60327-331-2_7

[90] Haab B.B., Dunham M.J., Brown P.O.: Genome Biology 2001, 2research0004.1.

http://dx.doi.org/10.1186/gb-2001-2-2-research0004

[91] Bai Y., Koh C.G., Boreman M. et al.: Langmuir 2006, 22, 9458. http://dx.doi.org/10.1021/la0611231

[92] Trzcinska R., Balin K., Kubacki J. et al.: Langmuir 2014, 30, 5015. http://dx.doi.org/10.1021/la500457q

[93] Szweda R., Szweda D., Kosowski D. et al.: Current Organic Chemistry 2017, 21, 1579.

http://dx.doi.org/10.2174/1385272821666170518170356

[94] Trzcinska R., Suder P., Bodzon-Kulakowska A. et al.: Analytical and Bioanalytical Chemistry 2013, 405, 9049. http://dx.doi.org/10.1007/s00216-013-7082-z

[95] Zhang F., Kang E.T., Neoh K.G., Huang W.: Journal of Biomaterials Science Polymer Edition 2001, 12, 515. http://dx.doi.org/10.1163/156856201300194252

[96] Inamori K., Kyo M., Matsukawa K. et al.: Analytical Chemistry 2008, 80, 643. 
http://dx.doi.org/10.1021/ac701667g

[97] Hu W., Liu Y., Lu Z., Li C.M.: Advanced Functional Materials 2010, 20, 3497.

http://dx.doi.org/10.1002/adfm.201001159

[98] Barbey R., Klok H.A.: Langmuir 2010, 26, 18219.

http://dx.doi.org/10.1021/la102400z

[99] Tugulu S., Arnold A., Sielaff I. et al.: Biomacromolecules 2005, 6, 1602.

http://dx.doi.org/10.1021/bm050016n

[100] Singh P., Onodera T., Mizuta Y. et al.: Sensors Actuators $B$ Chemistry 2009, 137, 403.

https://doi.org/10.1016/j.snb.2008.12.027

[101] Berrade L., Garcia A.E., Camarero J.A.: Pharmaceutical Research 2011, 28, 1480.

http://dx.doi.org/10.1007/s11095-010-0325-1

[102] Szweda R., Lipowska D., Silberring J. et al.: Polimery 2015, 60, 75.

http://dx.doi.org/10.14314/polimery.2015.075

[103] Yamada N., Okano T., Sakai H. et al.: Die Makromolekulare Chemie, Rapid Communications 1990, 11, 571. http://dx.doi.org/10.1002/marc.1990.030111109

[104] Okano T., Aoyagi T., Kataoka K. et al.: Journal of Biomedical Materials Research 1986, 20, 919. http://dx.doi.org/10.1002/jbm.820200707

[105] Krishnamoorthy M., Hakobyan S., Ramstedt M., Gautrot J.E.: Chemical Review 2014, 114, 10976. http://dx.doi.org/10.1021/cr500252u

[106] Nagase K., Yamato M., Kanazawa H., Okano T.: Biomaterials 2018, 153, 27.

https://doi.org/10.1016/j.biomaterials.2017.10.026

[107] Utrata-Wesołek A., Oleszko-Torbus N., Bochenek M. et al:: Polimery 2018, 63, 327.

http://dx.doi.org/10.14314/polimery.2018.5.1

[108] Isenberg B.C., Tsuda Y., Williams C. et al.: Biomaterials 2008, 29, 2565. https://doi.org/10.1016/j.biomaterials.2008.02.023

[109] Hatakeyama H., Kikuchi A., Yamato M., Okano T.: Biomaterials 2007, 28, 3632.

https://doi.org/10.1016/j.biomaterials.2007.04.019

[110] Takahashi H., Nakayama M., Shimizu T.: Biomaterials 2011, 32, 8830 .

https://doi.org/10.1016/j.biomaterials.2011.08.006

[111] Anderson C.R., Gambinossi F., DiLillo K.M. et al.: Journal of Biomedical Materials Research Part A 2017, 105, 2416.

http://dx.doi.org/10.1002/jbm.a.36100

[112] Adamus A., Komasa J., Kadłubowski S. et al.: Colloids Surfaces B Biointerfaces 2016, 145, 185. https://doi.org/10.1016/j.colsurfb.2016.04.050

[113] Uhlig K., Wischerhoff E., Lutz J.F. et al.: Soft Materials 2010, 6, 4262.

http://dx.doi.org/10.1039/COSM00010H

[114] Mendrek B., Żymełka-Miara I., Sieroń Ł. et al.: Journal of Materials Chemistry B 2018, 6, 641. http://dx.doi.org/10.1039/C7TB02748F

[115] Dworak A., Utrata-Wesołek A., Szweda D. et al.: ACS Applied Materials Interfaces 2013, 5, 2197. http://dx.doi.org/10.1021/am3031882

[116] Lesiak M., Sieroń Ł., Gutmajster E. et al.: European Journal of Dermatology 2019, 29, 126. http://dx.doi.org/10.1684/ejd.2019.3561

[117] Van Der Heide D.J., Verbraeken B., Hoogenboom R. et al.: Biomaterials and Tissue Technology 2017, 1, 1. http://dx.doi.org/10.15761/BTT.1000104

[118] Dworak A., Utrata-Wesołek A., Oleszko N. et al.: Journal of Materials Science: Materials in Medicine 2014, 25,1149 . http://dx.doi.org/10.1007/s10856-013-5135-7

[119] Macgregor M., Williams R., Downes J. et al:: Materials 2017, 10, 1081.

http://dx.doi.org/10.3390/ma10091081

[120] Oleszko N., Wałach W., Utrata-Wesołek A. et al.: Biomacromolecules 2015, 16, 2805.

http://dx.doi.org/10.1021/acs.biomac.5b00745

[121] Utrata-Wesołek A., Oleszko N., Trzebicka B. et al.: European Polymer Journal 2013, 49, 106. https://doi.org/10.1016/j.eurpolymj.2012.09.015

[122] Heinen S., Weinhart M.: Langmuir 2017, 33, 2076. http://dx.doi.org/10.1021/acs.langmuir.6b03927

[123] Fedorovich N.E., Schuurman W., Wijnberg H.M. et al:: Tissue Engineering Part C Methods 2011, 18, 33. http://dx.doi.org/10.1089/ten.tec.2011.0060

[124] Gauvin R., Chen Y.C., Lee J.W. et al.: Biomaterials 2012, 33, 3824. https://doi.org/10.1016/j.biomaterials.2012.01.048

[125] Hutmacher D.W., Schantz T., Zein I. et al.: Journal of Biomedical Materials Research 2001, 55, 203.

h t t p : / / d x.d o i . org / $10.1002 / 1097$ -4636(200105)55:2<203::AID-JBM1007>3.0.CO,2-7

[126] Williams J.M., Adewunmi A., Schek R.M. et al.: Biomaterials 2005, 26, 4817. https://doi.org/10.1016/j.biomaterials.2004.11.057

[127] Pati F., Jang J., Ha D.H. et al.: National Communications 2014, 5, 3935.

[128] Kim S.S., Utsunomiya H., Koski J.A. et al.: Annals of Surgery 1998, 228, 8.

http://dx.doi.org/10.1097/00000658-199807000-00002

[129] Paduszyński P., Aleksander-Konert E., Zajdel A. et al.: Cellular \& Molecular Biology Letters 2016, 21, 14. http://dx.doi.org/10.1186/s11658-016-0012-2

[130] Horbett T.A., Brash J.L.: ACS Symposium Series 1995, 602, i.

http://dx.doi.org/10.1021/bk-1995-0602.fw001

[131] Harding J.L., Reynolds M.M.: Trends in Biotechnology 2014, 32, 140.

https://doi.org/10.1016/j.tibtech.2013.12.004

[132] Utrata-Wesołek A.: Polimery 2013, 58, 685. http://dx.doi.org/10.14314/polimery.2013.685

[133] Liu L., Li W., Liu Q.: WIREs Nanomedicine and Nanobiotechnology 2014, 6, 599. http://dx.doi.org/10.1002/wnan.1278

[134] Thomas A., Müller S.S., Frey H.: Biomacromolecules 2014, 15, 1935. http://dx.doi.org/10.1021/bm5002608 
[135] Moore E., Thissen H., Voelcker N.H.: Progress in Surface Science 2013, 88, 213. https://doi.org/10.1016/j.progsurf.2013.03.003

[136] Utrata-Wesołek A., Wałach W., Anioł J. et al.: Polymer 2016, 97, 44. http://dx.doi.org/10.1016/j.polymer.2016.05.016

[137] Utrata-Wesołek A., Wałach W., Bochenek M. et al.: European Polymer Journal 2018, 105, 313. https://doi.org/10.1016/j.eurpolymj.2018.06.008

[138] Wang R.L.C., Kreuzer H.J., Grunze M.: Journal of
Physical Chemistry B 1997, 101, 9767. http://dx.doi.org/10.1021/jp9716952

[139] Chen S., Li L., Zhao C., Zheng J.: Polymer 2010, 51, 5283. https://doi.org/10.1016/j.polymer.2010.08.022

[140] Xue C.H., Guo X.J., Ma J.Z., Jia S.T.: ACS Applied Materials Interfaces 2015, 7, 8251. http://dx.doi.org/10.1021/acsami.5b01426

Received 13 VI 2019

\section{W kolejnym zeszycie ukażą się m.in. następujące artykuły:}

J. Kijeński - Tworzywa polimerowe w zrównoważonym rozwoju - od potrzeby użycia do potrzeby zużycia. Cz. I. Nie ma odwrotu od "plastików”

J. Kijeński - Tworzywa polimerowe w zrównoważonym rozwoju - od potrzeby użycia do potrzeby zużycia. Cz. II. Powrót do monomerów

A. Kozera-Szałkowska - Rynek tworzyw sztucznych - produkcja, zapotrzebowanie, zagospodarowanie odpadów

K. Borkowski - Zanieczyszczenia mórz i oceanów odpadami tworzyw sztucznych akceleratorem nowych regulacji prawnych $w$ tym zakresie

M. Dębowski, A. Iuliano, A. Plichta, S. Kowalczyk, Z. Florjańczyk - Recykling chemiczny poliestrów (j.ang)

A.K. Błędzki, K. Goracy, M. Urbaniak, M. Scheibe - Problematyka utylizacji wyrobów i odpadów z kompozytów polimerowych. Cz. I. Wielkość produkcji, utylizacja kompozytów z włóknami węglowymi, aspekty legislacyjne, recykling przemysłowy

M. Scheibe, M. Urbaniak, K. Goracy, A.K. Błędzki - Problematyka utylizacji wyrobów i odpadów z kompozytów polimerowych. Cz. II. „Złomowanie” kompozytowych rekreacyjnych jednostek pływających na świecie w perspektywie do roku 2030

D. Sykutera, M. Bieliński - Poprawa efektywności procesów recyklingu mechanicznego termoplastów o strukturze porowatej

D. Marciniak, P. Czyżewski, D. Sykutera, M. Bieliński - Recykling części eksploatacyjnych z ABS wykorzystywanych w przemysłowych drukarkach 3D (j. ang.)

K. Butlewski - Beztlenowa fermentacja i mikrofalowa piroliza w recyklingu odpadów organicznych (j. ang.)

W. Sikorska, M. Musioł, J. Rydz, M. Kowalczuk, G. Adamus - Kompostowanie przemysłowe jako metoda zagospodarowania odpadów z materiałów poliestrowych otrzymywanych z surowców odnawialnych 